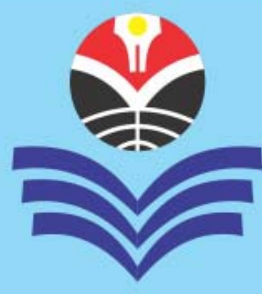

Published every March and September

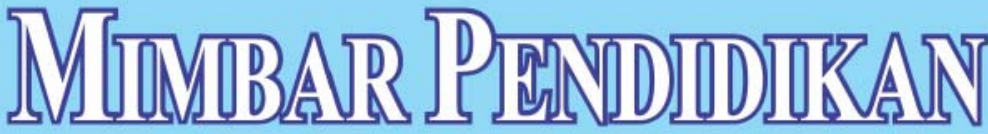

Jurnal Indonesia untuk Kajian Pendidikan

NERISSA S. TANTENGCO \& RODOLFO L. MARAMAG

\title{
Examining Gender Responsiveness of the Philippine Basic Education Reform: An Analysis of the K-12 Araling Panlipunan or Social Studies Curriculum
}

ABSTRACT: This study provides an in-depth analysis on how gender issues, concepts, and principles were integrated in the recent K-12 Araling Panlipunan or Social Studies curriculum provided by the Department of Education in the Philippines. The study employed descriptive analysis of the K-12 Araling Panlipunan or Social Studies curriculum content covering grades one to ten. Findings have shown that promoting gender-fair education is a commitment of different educational institutions in the country, both private and public. Social Studies are the curriculum vehicle of the K-12 Basic Education Reform to promote active citizenship and social transformation. The new Social Studies Curriculum of the K-12 Basic Education Reform tries to respond in integrating gender-principles and concepts in the teaching-learning process by providing curriculum content that recognizes women's significance in the society as product of historical and cultural processes. The school serves as an agent of social transformation by creating curricula that provide learning experiences that will harness social criticism and action towards contemporary issues in the country.

KEY WORD: Development, gender-fair education, Social Studies curriculum, and transformative education.

ABSTRAKSI: "Mengkaji Ketanggapan Gender dalam Reformasi Pendidikan Dasar di Filipina: Sebuah Analisis terhadap K-12 Araling Panlipunan atau Kurikulum Ilmu Pengetahuan Sosial”. Penelitian ini menganalisis secara mendalam isu-isu gender, konsep, dan prinsip-prinsip yang terintegrasi dalam kurikulum terbaru K-12 Araling Panlipunan atau Kurikulum Ilmu Pengetahuan Sosial, yang diberikan oleh Kementerian Pendidikan di Filipina. Penelitian ini menggunakan analisis deskriptifterhadap isi K-12 Araling Panlipunan atau Kurikulum Ilmu Pengetahuan Sosial yang meliputi kelas satu sampai sepuluh. Temuan menunjukkan bahwa mempromosikan pendidikan gender yang adil merupakan komitmen dari lembaga pendidikan yang beragam di negara ini, baik swasta dan negeri. Ilmu Pengetahuan Sosial adalah wahana bagi kurikulum Reformasi Pendidikan Dasar K-12 untuk mempromosikan warganegara yang aktif dan transformasi sosial. Kurikulum baru Ilmu Pengetahuan Sosial dalam Reformasi Pendidikan Dasar K-12 mencoba merespons persyaratan untuk mengintegrasikan konsep dan prinsip gender dalam proses belajar-mengajar dengan menyediakan materi kurikulum yang mengakui pentingnya perempuan dalam masyarakat sebagai produk dari proses sejarah dan budaya. Sekolah berfungsi sebagai agen transformasi sosial dengan menciptakan kurikulum dan memberikan pengalaman belajar yang akan memanfaatkan kritik sosial dan tindakan nyata terhadap isu-isu kontemporer di negara ini.

KATA KUNCI: Pembangunan, pendidikan adil bagi gender, kurikulum Ilmu Pengetahuan Sosial, dan pendidikan transformatif.

About the Authors: Nerissa S. Tantengco, Ph.D. is a Professor in Southeast Asian Studies at the (Philippine Normal University). Rodolfo L. Maramag, M.A. is a Lecturer in Philippine Studies at the PNU in Manila, the Philippines. Corresponding authors is: tantengco.ns@pnu.edu.ph

How to cite this article? Tantengco, Nerissa S. \& Rodolfo L. Maramag. (2016). "Examining Gender Responsiveness of the Philippine Basic Education Reform: An Analysis of the K-12 Araling Panlipunan or Social Studies Curriculum” in MIMBAR PENDIDIKAN: Jurnal Indonesia untuk Kajian Pendidikan, Vol.1(1) Maret, pp.37-54. Bandung, Indonesia: UPI Press.

Chronicle of the article: Accepted (December 15, 2015); Revised (January 15, 2016); and Published (March 11, 2016). 
NERISSA S. TANTENGCO \& RODOLFO L. MARAMAG,

Examining Gender Responsiveness of the Philippine Basic Education Reform

\section{INTRODUCTION}

Education is a fundamental process that shapes the holistic development of an individual, particularly his/her personal and social development. It serves as the most important tool for empowerment and to be actively involved in the social, economic, and political affairs of his/her community and the country as a whole.

Among the different social institutions, school plays significant role in developing the minds of the people, and educating each individual about the norms of the society and the standards on how each person should act and behave. It also contributes on how an individual looks upon him/herself (Lorber, 2008; and Bowles \& Gintis, 2009).

Thus, gender identity is being molded in the teaching-learning process the school provides. If there is unequal footing in defining and shaping such identity, it will result to gender bias. Moreover, such thinking will develop expectations and gender stereotyping. It will perpetuate differentiated functions and training for male and female from early stages of life to adulthood (Guerrero, 2008; and Wessleyley, 2009).

On the other hand, the school could also be a venue for transformation. Transformative education is a systematic, conscious process of molding the students into a conscious, active citizen who is committed to social transformation. The goal of transformative education is to equip students with relevant knowledge and skills for critical and creative thinking, making them socially aware about the emerging needs of transforming the values and institutions for genuine democracy and development.

It seeks to open the minds of students to social realities for correctly analyzing the social problems that beset the Philippine society. In the end, transformative education will serve as a response to mold active, committed, democratic, and national citizenry (Tantengco, 2001).
Setting new direction in education will lead to social transformation. And in speaking of such, there have been two conferences on women that contributed in setting new directions in education towards liberation and transformation of the different societies in the world. Thirty-eight years ago in Mexico City, the First World Conference on Women was held. It called for women's access to education, proper health care, equal pay and opportunities for women in labor, and respect for their human rights.

Despite of this attempt, discrimination and violence against women are still rampant. Women's access to education and economic opportunities are still restricted and the "glass ceiling" hinders them to acquire advancement in the field of politics and the economy. To reaffirm the commitment, especially of the government in combating discrimination and violence against women, the Fourth World Conference on Women was held. It was known as the Beijing Declaration and Platform for Action (UN, 2013).

Government mechanisms should integrate gender perspective, most especially when it comes to projects and programs. There are twelve critical areas of concern, namely: poverty, education and training, health, violence, armed-conflict, economy, decisionmaking, institutional mechanism, human rights, media, environment, and the girl child. Educational platform recommended action for equal access to education; close gender gap in the primary and secondary school education by the year 2000; and achieve universal education in all countries before the year 2015; reduce female illiteracy rate at least one half of its 1990 level; develop nondiscriminatory education and training; and promote lifelong education and training for girls and women.

The $21^{\text {st }}$ century education is geared towards social transformation. It involves educational innovations to re-orient the minds of the youth to become empowered. This will help one in determining and 
analyzing the existence of marginalization, subordination, stereotyping of roles, and personal and structural violence of different sectors in the Philippine society.

Making the curriculum gender responsive will make ways to engage the students draw ideas and practices from their social context, enabling boys and girls acquire full understanding on how they can position themselves as female and male. A gender-fair curriculum will help students in learning how to respect, commit themselves to improve the needs and welfare of both male and female, watch for biases, share information, and build a network of colleagues with a strong commitment to gender equity (Tantengco, 2001).

Now that the primary institution of the country for education, the Department of Education in the Philippines, is on its way to reform the basic education sector, how can it make the curriculum gender responsive? What significant role does it serve to promote gender-fair education? And most importantly, how does it cater contemporary issues such as gender? This questions need answers, hence this study.

\section{STATEMENT OF THE PROBLEM, SIGNIFICANCE OF THE STUDY,} AND SCOPE AND DELIMITATION

This study aims to find out how gender issues, concepts, and principles were integrated in the recent K-12 Araling Panlipunan or Social Studies Curriculum provided by the Department of Education in the Philippines as part of the institutions' advocacy to promote gender-fair education in the basic education sector.

Specifically, this study seeks to: (1) describe what gender-fair education is in the Philippine context; (2) describe the K-12 Araling Panlipunan or Social Studies Curriculum in terms of: conceptual framework, scope and sequence, general objectives, theme, and topics of each grade level; (3) identify specific content and learning competencies in the K-12 Araling Panlipunan Curriculum where gender issues, concepts, and principles were integrated; and (4) describe the role of education and school as a social institution in addressing contemporary issues, such as gender and other related concepts.

There is little literature about genderresponsiveness of the curriculum (Monk, Betteridge \& Newhall, 2007). This study is an attempt to contribute in this body of knowledge considering the new education reform that is being offered in the basic education sector in the country.

This study is deemed significant, because it tries to analyze the new curriculum and how gender responsive it is. Data and other information that was provided by this study will be of help to some researches, whose objective is to assess gender equity in the curriculum and the promotion gender-fair education.

Teachers, of Social Studies to be specific, will acquire an idea from this study on how gender principles and concepts should be integrated in their lessons. Curriculum developers will also benefit from this study, because they will have an idea on how they can make the curriculum they are designing gender responsive. The schools and other institutions will also realize in reading this study on how important it is to foster genderresponsive projects and programs.

Lastly, this study will help Filipino citizens to realize the importance of being active, critical, and responsible of their community as they engaged themselves in different contemporary issues that beset the Philippine society.

This study is limited to the analysis of the K-12 Araling Panlipunan or Social Studies Curriculum. It focused only in one aspect of the curriculum, which is content from grades one to ten considering the learning competencies that would best describe the intention or objective of this study.

Among the core subjects of the current 
basic education reform, Social Studies was chosen by the researcher to be analyzed for it embodies the principles of responsible citizenship and it offers venue for social criticism and action towards contemporary issues besetting the Philippine society. In addition, some of the content derived from the curriculum was written in Filipino to preserve what the curriculum developers intend in designing the subject and to avoid mistakes in language translations since the researcher does not claim expertise in translating the full text from Filipino to English.

\section{REVIEW OF RELATED LITERATURE AND THEORETICAL FRAMEWORK}

There is a dearth in number of literature that was written about the gender-fair curriculum, specifically in the Social Studies area. In this section, the researcher tried to weave some studies that are connected to gender-fair curriculum and the promotion of gender-fair education in Social Studies.

Social Studies is a learning area in basic education that integrates the social sciences and humanities. One of its objectives is to make learners critical of the different issues in the society. One the issues concern the marginalized sector, specifically women and how different forces in the society contribute in perpetuating gender bias and stereotyping (Clark \& Page, 1999; and Frankel \& Lloyd, 2009). It is only befitting to look on how the teaching-learning process in Social Studies responds to this issue, including the instructional materials being used in the subject.

N. Tantengco (2001) conducted a study that assessed gender equity in the Secondary Social Studies Curriculum that served as a basis for a proposed guide in preparing gender-fair instructional materials. Findings revealed that learning environment, including the color and pictures inside the classroom; arrangement of chairs; content courses; instructional materials such as textbook materials; school policies; instructional processes such as languages used in the classroom as well as student to student interaction are strongly suggestive of gender biases in a Social Studies classroom (Tantengco, 2001).

Thus, it inhibits opportunities for sharing and interacting with the opposite sex in the classroom. Secondary Social Studies curriculum did not include gender concepts and principles that will equalize women's contributions and achievements; another, power relations, types of roles, teacherstudent relationships, student performance, and self-image of boys and girls inside the classroom were deliberately equated by teachers by giving them the same opportunities to perform and excel in Social Studies subject.

In addition to that, there was a significant difference between the gender concepts of male and female students, male and female teachers, public and private school students and public and private school teachers; and, lastly, demonstrating the equality of genders and tapping their fullest potentials can lead in setting the framework for gender equity in the curriculum. Evolving a gender fair curriculum in Social Studies curriculum will help in establishing women's place and equal status with men in the next millennium.

Z. Reyez (1998) conducted an analysis of selected Asian history textbooks being used in Philippine secondary schools. Her study revealed the writer's patriarchal construction of gender is reflected in the writer's (1) point of view, (2) handling and interpretations of facts and events, (3) definition of concepts, (4) images, and (5) in-depth analysis (Reyez, 1998).

On the other hand, Ruby Ann L. Ayo (2013) conducted a study that looked into the integration of gender concepts and practices in the teaching of Philippine History in Bicol University for year 2011-2012. The result of her study showed that: (1) Gender fair education is integrated in Mandated Subject 
1 - Philippine History as shown in the gender concepts and practices introduced by the faculty teaching the subject; (2) Gender fair practices suggests the need for a structured integration of gender practices not only as the situation favors based on the reactions of the learners during discussion and/or class interactions but as long as the subject matter deems it appropriate; and (3) The lesson exemplars developed are samples of genderfair education materials reflective of specific gender education key thrusts, concepts, and practices imply the feasibility of structured integration gender fair education in the teaching of Philippine History as one of the General Education Courses in Social Sciences (Ayo, 2013).

As emphasized by the researcher, this study is an attempt to contribute to the limited body of literature about gender equity in the curriculum and the promotion of gender-fair education in the K-12 Basic Education Reform. However, this research endeavor primarily focuses in the curriculum content of Social Studies.

B. Hey (2010) posits that the curricula hold the potential to enhance the inequality of opportunities existing in society, to address one gender more strongly than the other, to generate unequal success opportunities, and to strengthen the already existing gender stereotypes. She offered several ways on how it can be prevented. First, by ensuring that the needs of the students, men, and women alike are addressed at all levels of curriculum development. Second, by ensuring all students, both men and women, can both benefit from the curriculum content. And lastly, third, by offering learning contents that are gender-sensitive in a science-based manner, wherever relevant (Hey, 2010).

It is argued that rights, opportunities, and privileges should not be gender-biased but still, in real life, stereotyping, gender gap, and discrimination are often observed. On the other hand, actions to equalize men and women are strong in different countries.
For the last 100 years, equalization of rights and duties of both men and women are strengthened. Specifically, women's rights such as the right to vote, right to own property, and equality in legislation have been achieved as much as their male counterparts enjoy such rights. Likewise, access to education and labor participation has quickly matched those of the males. However, differences in equal opportunities are still evident today (Hey, 2010).

To contextualize the idea that real equal opportunities only occur in certain stages and areas of life, there are observable instances in the Philippine setting. In the private sphere, domestic violence involving Filipino husbands and wives are still lobbied for justice. Unequal share of household work are still experienced by Filipino women. Unfortunately, wives housework is labelled less important since it does not equate any financial gain unlike the work of their husbands. In the public sphere, specifically education, there is curriculum content that stereotype women making them inferior of men. Cases of sexual harassment are present at work. Courses in education and positions in some companies are gendered (Perez, 2008; NCRFW, 2009; and Sobritchea ed., 2009).

It is undeniably that education is the most important tool to re-construct and re-orient the minds of the people in the different images and categories assigned to gender by the society. B. Hey (2010), further, argued that curriculum content can help accentuate the inequality of opportunities.

It is in this light that gender-fair education is advocated. Z. Reyez (2012) argued that gender-fair education aims to promote the teaching and learning of gender equity, highlighting female experiences as product of historical and cultural processes. She further elaborated that gender-fair education works on the following principles: (1) men and women are born equal, and so they must be given equal opportunities to develop their potential; (2) all students have the right to 
a gender-fair learning environment; (3) all education programs and career decisions should be based on the student's interests and abilities, regardless of gender; (4) gender-fair education incorporates issues of social class, culture, ethnicity, religion, sexual orientation, and age; (5) gender-fair education requires sensitivity, determination, commitment, and vigilance; and (6) the foundation of gender-fair education is the cooperation and collaboration among students, educational organizations, and other relevant institutions (Reyez, 2012).

Z. Reyez (2012) also stressed out that these principles must guide teachers, school administrators, curriculum writers, and textbook writers in eliminating patriarchal ideology in the classroom. In addition, Keith in 1997, as cited by in Z. Reyez (2012), cited the following advocacies by gender-fair educators:

(1) be committed to learning and practicing equitable teaching by being committed to improving the needs and welfare of both male and female students; (2) use gender-specific terms to market opportunities, for example, if a technology fair has been designed to appeal to girls, mention girls clearly and specifically, many girls assume that genderneutral language in non-traditional fields means boys; (3) modify content, teaching style, and assessment practices to make non-traditional subjects more relevant and interesting for female and female students; (4) highlight the social aspects and usefulness of activities, skills, and knowledge; (5) recognize comments received from female students, and explore social, moral, and environmental impacts of decisions, especially those that would affect women; (6) when establishing relevance of material, consider the different interests and life experiences that girls and boys may have; (7) choose a variety of instructional strategies, such as cooperative and collaborative work in small groups, opportunities for safe risk taking, hands-on work, and opportunities to integrate knowledge and skills, e.g. science and communication; (8) provide specific strategies, special opportunities, and resources to encourage students to excel in areas of study in which they are typically underrepresented;
(9) design lessons to explore many perspectives and to use different sources of information, refer to male and female experts; (10) manage competitiveness in the classroom, particularly in areas in which male students typically excel; (11) watch for biases, for example, in behavior or learning resources, and teach students strategies to recognize and work to eliminate inequities they observe; (12) be aware of accepted gender-biased practices in physical activity, e.g. in team sports, funding for athletes, and choices in physical education programs; (13) do not assume that all students are heterosexual; (14) share information and build a network of colleagues with a strong commitment to equity; (15) model non-biased behavior: use inclusive parallel or gendersensitive language, question and coach male and female students with the same frequency, specificity, and depth, allow quiet students sufficient time to respond to questions; (16) have colleagues familiar with common gender biases observe your teaching and discuss any potential bias they may observe; and (17) be consistent over time (Reyez, 2012).

The concepts and principles mentioned above are helpful in creating a genderfair curriculum. The school, as a social institution, serves as the second agent of socialization. It has the power and influence to transform the minds of the people. It should begin in making the curriculum content gender-responsive and transforming the teachers and other school personnel to become gender-sensitive individuals.

\section{METHODS}

This study employed descriptive analysis of the K-12 Araling Panlipunan or Social Studies Curriculum content and learning competencies covering grades one to ten. The document that was used in this study is the Curriculum Guide for Social Studies released by the Department of Education in the Philippines, dated December 2013.

The analysis involves critiquing of the curriculum content based on the principles of gender-fair education provided by B. Hey (2010) and Z. Reyez (2012). The analysis of the content follows the expanding horizon 
curriculum design of Social Studies, both in primary and secondary.

Data Gathering Procedure. After the research proposal was approved, the researcher visited different libraries to search for related studies and other references. The researcher also requested to the school administrator of the school, where the researcher is working a copy of the most recent K-12 Araling Panlipunan or Social Studies Curriculum guide that was released by DepEd (Department of Education).

Soon after the requested document was received, analysis of the document was started by the research. It took two weeks for the researcher to study the whole document. The researcher even sends an email to some Professors, who are also working on genderfair curriculum to ask for some advice.

No interviews were conducted in this study, since its primary method is document analysis. However, some studies were adapted so to have an idea on how the document must be analyzed considering the objectives of the study.

\section{PRESENTATION, ANALYSIS, AND INTERPRETATION OF DATA}

Gender-Fair Education: The Philippine

Experience. The advocacy of promoting gender-fair education in the Philippines is one of the milestones that marked the education sector in terms of transformation and setting new directions. Even though there are already existing policies and programs that promote gender-responsive environment in schools and the curriculum in particular, there is a dearth in the number of studies about gender-fair education in the Philippines.

This might justify the need to strengthen institutional mechanisms in order to combat gender stereotyping and the gap between the roles of men and women in the society, most especially as it is reflected in some schools in the country. The discourse about gender and the assigning of roles has been a critical issue in the teaching-learning process. Producing studies about this advocacy and the promotion of such will contribute in closing the gap and achieving gender equality.

This section will discuss some of the current attempts to promote gender-fair education in the Philippines. Since the researcher did not conduct any interview, it employed library-research methods to answer the first objective.

M. Labajo et al. (2007), in their study, have presented current initiatives in the practice of gender equality in Philippine education, particularly mentioning some brief- write ups like in the case of St. Scholastica's College, Miriam College, and the Department of Education (Labajo et al., 2007). In the case of St. Scholastica's College, the school had begun promoting gender equality in education by initiating the Women's Studies program way back in 1985 , as they celebrate their $10^{\text {th }}$ year of promoting education for social transformation.

The primary thrust of the program is to instill gender awareness in the academe as inspired by the growing feminist movement in the 1980s. It eventually led to the incorporation of Women's Studies in their general education program. It was then followed by the establishment of the Institute of Women's Studies in 1988, as an affiliate unit of the college tasked to institutionalize and systematize the pursuit of a feminist pedagogy in the College. They provided as course offering entitled "Training Workshop on Engendering the School System”.

It seeks to provide venue for educators and school administrators to reflect on their experiences, individually and collectively, for a deeper understanding of their experiences and situations as women and men in an educational institution. Furthermore, it also seeks to provide venue for sharing strategies towards mainstreaming the gender perspective within the classroom and schools, and practicing gender fairness in their respective spheres of work. The College also 
has Gender Studies for Men, which primary purpose is to articulate the participating men's vision of society and identity roles that men play in it, revisit and challenge concepts of masculinity and how they contribute to gender inequity and reconstruct the concept of masculinity that is more gender sensitive (Dionisio, 2008; and UN, 2009).

Miriam College, on the other hand, had created its own Gender Mainstreaming Committee in 2001, as an institutional mechanism to put forward their objective of gender-fair education. The committee is composed of representatives of different subunits of the College, such as WAGI (Women and Gender Institute), MAE (Miriam Adult Education), Graduate School, College of Arts and Sciences, CSC (Child Study Center), and High and Grade Schools. The Gender Mainstreaming Committee has its mandate to work for the realization of a gender-fair campus.

The DepEd (Department of Education) in the Philippines had also acknowledged that the content of education conveys fundamental message, which may discriminate or promote the elimination of discrimination against women. The institution went further stating that schools play a pivotal role in reinforcing and perpetuating sex-role stereotyping and sexist concepts still found in the curricula, textbooks, and instructional materials. To promote gender-fair education in the public school system, DepEd produced Gender and Development Exemplars.

It has set the following goals: (1) institutional organization goals: to ensure the promotion and protection of the dignity and self-worth of both sexes by integrating and/ or infusing core messages and related values on gender-fair education in the curricula across the three levels of education; (2) to foster a sense of personal growth and dignity and respect for the abilities and rights of the people of all races, ethnic background of both sexes; (3) to develop awareness of the gender biases and stereotyping that have been culturally perpetuated in order to be able to rectify these.

It also has eight key concepts with corresponding indicators which are as follows:

First, Shared Parenting. In families, both father and mother share in the childrearing joys and responsibilities to develop the nurturing and emotive capabilities of each. Parents exercising shared parenting are better role models for their children. In other families, all supportive adults in the household can share parenting.

\section{Second, Shared Home Management.} Both parents are capable income earners and providers for the family. Both parents share household chores and attended to the family needs, such as health care, recreation, and value inculcation. Economically able household members have the responsibility to share in providing for the family needs. Family budgeting is a joint concern.

\section{Third, Shared Decision Making.} Decision making is shared at all levels within the family. Openness between husband and wife is encouraged in all major and minor matters affecting family. Family council for consultation should be encouraged to allow parents, children, and other household member to speak and listen freely. Determining the number of children and/or choice of fertility management to be used is a joint decision of husband and wife.

Fourth, Equalized Opportunities. Equal opportunity in education, non-traditional livelihood or occupation, health services, credit and loan programs provided to both male and female e.g. admission policies, scholarship policies, training guidelines should be reviewed. Both male and female should have an access to resources, i.e. information, training, and technology.

Fifth, Equalized Representation in Public Affairs and Enhance Participation. Provide opportunities for women to track their careers in the bureaucracy, business, and 
NGOs (Non-Governmental Organizations). Encourage women to enter electoral politics and to have a voice in government affairs.

Sixth, Make Women's Roles and Contributions Visible, Valued, and Recognized. Make women affirm themselves nurturers, mothers and producers. Recognized the role of the women as farmers, fisher-folks, traders, self-employed, and employers. Women have proven themselves to be creative, versatile, intelligent, enterprising, and hardworking. They can be self-propelled, self-directed, and can handle multifarious jobs. They can accept challenge with tack, initiate savings and utilize resource efficiently, and excel in music entertainment and the arts. Women can be active in the field of science and can involve themselves in environmental protection, livelihood projects, continuing education, and community work.

Seventh, Eliminate All Forms of Violence Against Women. Make women realize that domestic violence is a social concern and not just a personal matter/ problem and that they are entitled to help/ assistance. All forms of violence against women are human right violations. Domestic violence stems from unequal power relations between men and women, parents and children. Consider existence of gender bias in the courts.

Eighth, Ensure Non-Sexist Socialization. Observe and practice non-sexist child rearing practices at home (parent education). Provide non-sexist schooling (textbooks, teacher training, including hidden curriculum). Develop media awareness training for parents and teachers. Highlight the role and the image of women in religion.

In order to fully integrate the gender perspective in the educational system, Orientation-Workshop on the Use of GAD (Gender and Development) Lesson Exemplars is conducted among teachers. At the end of the training, each Division is required to formulate an Action Plan on
Gender and Development. At present, DepEd (Department of Education) in the Philippines still conduct Trainor's Training Workshops for GAD Lesson Exemplars (NCRFW, 2008 and 2010).

The different institutions that were mentioned in the study of M. Labajo et al. (2007) only justified the continuum advocacy of promoting gender-fair education in the country. Likewise, it gives an idea on how gender-education has been contextualized in the Philippine setting.

Social Studies: The Curriculum Vehicle for Active Citizenship and Social Transformation. In this section, the K-12 Araling Panlipunan or Social Studies Curriculum will be described based on the following aspects: (1) Conceptual Framework; (2) Definition, Scope, and Sequence; (3) Objectives; (4) Themes; (5) Skills; and (6) Topics for each Grade Level.

First, Social Studies Curriculum: Conceptual Framework. Figure 1 shows the K-12 Araling Panlipunan or Social Studies Curriculum. It is based on the Education for All 2015 and the K-12 Philippine Basic Education Curriculum Framework. Its primary objective is to foster $21^{\text {st }}$ century skills among learners to produce "functionally literate and developed Filipino". The curriculum gears toward the formation of a citizen that is:

\section{[...] mapanuri, mapagmuni, mapanagutan, produktibo, makakalikasan, makabansa, at makata na may pambansa at pandaigdigang pananaw at pagpapahalaga sa mga usaping pangkasaysayan at panlipunan (DepEd, 2013).}

It is anchored in following theories: constructivism, collaborative learning, experiential, and contextual learning. It employs teaching methods that are thematic or conceptual, investigative, integrative, interdisciplinary, and multidisciplinary.

The curriculum considers the Pillars of Learning, namely Learning to Know, Learning to Be, Learning to Do, and 


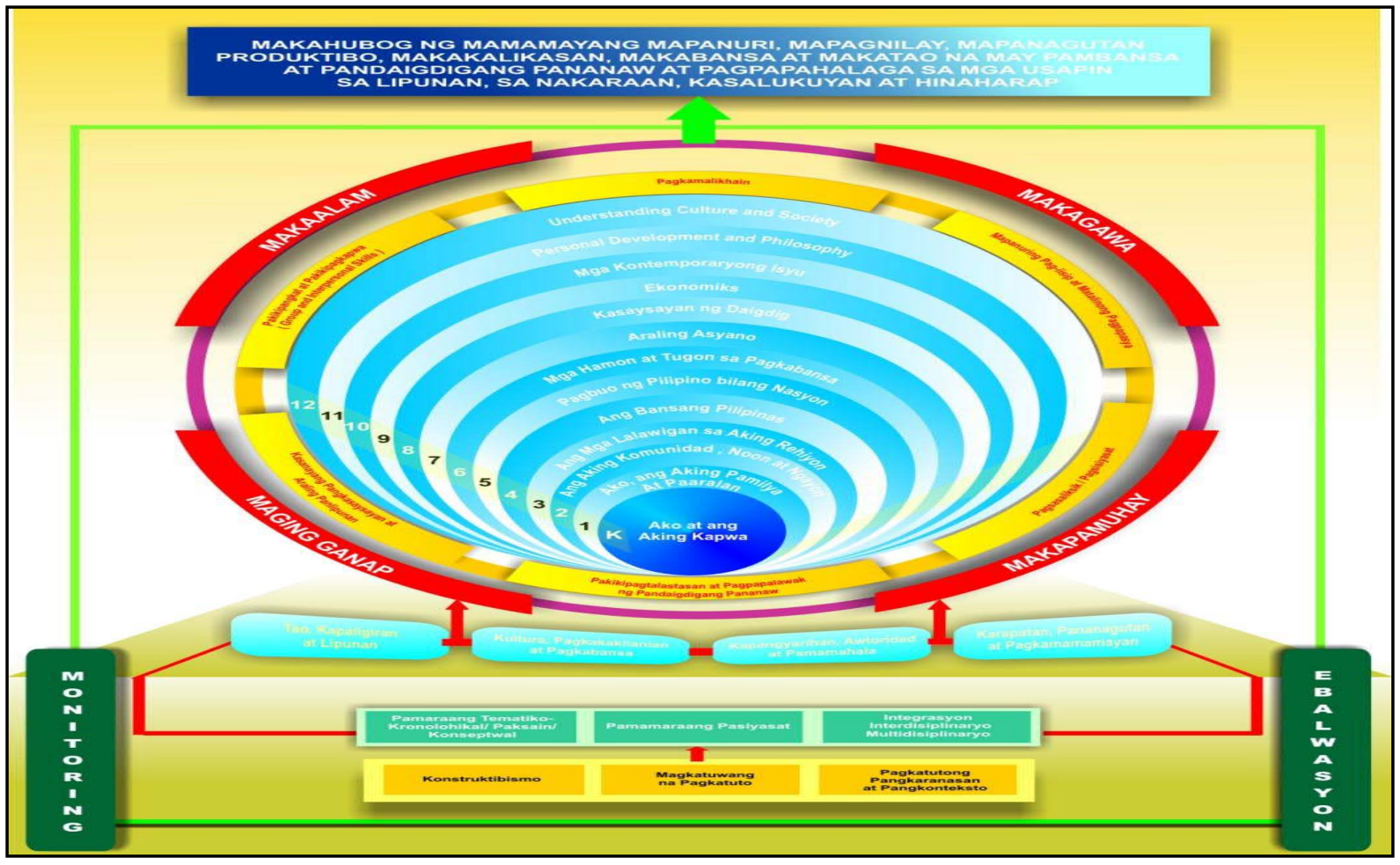

Figure 1:

Social Studies Curriculum Conceptual Framework

(Source: DepEd, 2013)

Learning to Live Together (NCRFW, 2010). It does not call to memorize certain facts or concepts but rather understand and make sense of it thus contextualizing the learning being accumulated in the subject and apply it in real life.

\section{Second, Social Studies Defined: Its}

Scope and Sequence. The K-12 Araling Panlipunan Curriculum Guide defines the Social Studies, as follows:

[...] pag-aaral ng mga tao at grupo, komunidad at lipunan, kung paano sila namuhay at namumuhay, ang kanilang ugnayan at inteaksyon sa kapaligiran at isa't isa, ang kanilang mga paniniwala at kultura, upang makabuo ng pagkakakilanlan bilang Pilipino, tao at miyembro ng lipunan at mundo at maunawaan ang sariling lipunan at ang daigdig, gamit ang mga kasanayan sa pagsasaliksik, pagsisiyasat, mapanuri at malikhaing pag-iisip, matalinong pagpapasya, likas-kayang paggamikt ng pinagkukunang-yaman at mabisang komunikasyon (DepEd, 2013).

\section{Third, Social Studies Curriculum} Objectives. The Social Studies Curriculum general objective, as stated in the K-12 Araling Panlipunan Curriculum Guide, is as follows:

[...] makalinang ng kabataan na may tiyak na pagkakakilanlan at papel bilang Pilipinong lumalahok sa buhay ng lipunan, bansa at daigdig. Kasabay sa paglinang ng identidad at kakayanang pansibiko ay ang pag-unawa sa nakaraan at kasalukuyan at sa ugnayan sa loob ng lipunan, sa pagitan ng lipunan at kalikasan, at sa mundo, kung paano nagbago at nagbabago ang mga ito, upang makahubog ng indibiduwal at kolektibong kinabukasan. Upang makamit ang mga layuning ito, mahalagang bigyang diin ang mga magkakaugnay na kakayahan sa Araling Panlipunan: (1) pagsisiyasat; (2) pagsusuri at interpretasyon ng impormasyon; (3) pananaliksik; (4) komunikasyon, lalo na ang pagsulat ng sanaysay; at (5) pagtupad sa mga pamantayang pang-etika (DepEd, 2013). 


\section{Fourth, Themes of the Social Studies}

Curriculum. The K-12 Araling Panlipunan

Curriculum has the following themes:

(1) Tao, Lipunan at Kapaligiran; (2)

Panahon, Pagpapatuloy at Pagbabago;

(3) Kultura, Pagkakakilanlan at

Pagkabansa; (4) Karapatan, Pananagutan

at Pagkamamamayan; (5) Kapangyarihan,

Awtoridad at Pamamahala; (6) Produksyon,

Distribusyon at Pagkonsumo; and (7)

Ugnayang Panrehiyon at Pangmundo

(DepEd, 2013).

\section{Fifth, Skills to be Honed in the Social}

Studies Learning Area. It has been stressed out that the K-12 Araling Panlipunan

Curriculum will not only be contentbased but rather competence-based. The competencies in Social Studies Learning Area are interconnected. It is also intended to be developmental to fit the grade or year level of student starting from the most basic competencies going to the more complex one, as follows:
1. Pagsisiyasat.
2. Pagsusuri at Interpretasyon ng Datos.
3. Pagsusuri at Interpretasyon ng Impormasyon.
4. Pagsasaliksik.
5. Komunikasyon.
6. Pagtupad sa pamantayang pang-etika
(DepEd, 2013).

Sixth, Topics for Each Grade Level. The K-12 Araling Panlipunan (Social Studies Curriculum) has the following topics for each of the grade level. It follows the expanding horizon curriculum design:

$\mathrm{K}$ - Ako at ang Aking Kapwa.

Grade 1 - Ako, ang Aking Pamilya at Paaralan.

Grade 2 - Ang Aking Komunidad, Ngayon at Noon.

Grade 3 - Ang mga Lalawigan sa Aking Rehiyon.

Grade 4 - Ang Bansang Pilipinas.

Grade 5 - Pagbuo ng Pilipinas bilang Nasyon.

Grade 6 - Mga Hamon at Tugon sa Pagkabansa.

Grade 7 - Araling Asyano.

Grade 8 - Kasaysayan ng Daigdig.

Grade 9 - Ekonomiks.

Grade 10 - Mga Kontemporaryong Isyu

(DepEd, 2013).

\section{Social Studies Curriculum: Analysing}

Gender Responsiveness. This section

shows the analysis and interpretation of the curriculum content of each of the grade levels, from grades one to ten, of the K-12 Araling Panlipunan or Social Studies Curriculum. Looking into the learning competencies, the researcher takes into consideration in the curriculum content analysis the gender principle and concepts provided by B. Hey (2010) and Z. Reyez (2012) for gender-fair education as discussed in the theoretical framework of this study.

Grade One: Ako, ang Aking Pamilya at Paaralan. Social Studies Curriculum, or Araling Panlipunan 1, basically, focuses on the construction of the student of his/ her idea about him/herself with respect to the immediate social institution, where he/ she belongs, the family, and the school. It covers discussion about knowing oneself and identity, getting to know more about his/her family, the rules and values that his/ her family has at home. It was followed by discussion about the school and the values it teaches him/her. The course also includes care for the environment.

This level of the Araling Panlipunan or Social Studies Curriculum deemed to be one of the most critical parts, because it provides venue for the students, boy and girl, on how they think of themselves. On how they should act, behave, and their preferences. This part highlights the importance of the family. It is imperative that the teacher-facilitator of this subject or grade level should be gendersensitive to avoid gender bias and stereotyping whenever teaching the children on what particular housework does a family member do with regards to his/her gender.

As the subject also focuses in schooling, it is implied through the hidden curriculum the assigning of roles for each gender. It is important that the teacher-facilitator is critical and sensitive of this matter.

Grade Two: Ang Aking Komunidad Noon at Ngayon. Social Studies Curriculum, 
or Araling Panlipunan 2, offers discussion and activities about the community. It includes getting to know what an ideal community is and contextualizing the community where the learners live. Political, economic, and socio-cultural aspects are also being discussed in this part however in a more simple manner that would fit the grade level of the students. There are discourses about culture, governance, and livelihood in the community. Aside from taking into account the origin of his/her community, right and duties of a responsible citizen is also part of the course.

Although it is not literally written in the course guide, but it is implied in learning competencies of Araling Panlipunan 2, or Social Studies Curriculum, the need to understand what is a right and what is a duty or responsibility of a citizen. To make it gender-responsive, the discourse should include concepts such as equality in terms of rights, opportunities and privileges. One of the learning competencies states that:

Natutukoy ang iba pang tao na naglilingkod at ang kanilang kahalagahan sa komunidad (e.g. guro, pulis, brgy.tanod, bumbero, nars, duktor, tagakolekta ng basura, kartero, karpintero, tubero, atbp (DepEd, 2013).

It is imperative that no gender is particularly assigned in a particular work or profession being enumerated in the competencies.

Grade Three: Ang mga Lalawigan sa Aking Rehiyon. Social Studies Curriculum, or Araling Panlipunan 3, covers discussion about basic geography. It includes discussion about regionalization of the country taking into the consideration the physical geography of the place or region. Its unique culture, means of livelihood and political affairs. It also gives emphasis on the interaction of men and women with his/her environment.

There is no specific competency that obviously focused on gender, however; there are some learning competencies that can be integrated with gender principle. For example, the competency below:

Naipagmamalaki ang mga bayani ng sariling lalawigan at rehiyon (DepEd, 2013).

The competency is focused on local history and local heroes. However, to make it gender-responsive, the content should include herstory and heroines. It should not merely focus on gender-biased conceptualization of heroes, like they are physically strong and that heroes are mostly male (Patajo-Legasto, 2005; and Landis, 2008).

When it comes to culture, the discourse should also take into consideration women's contributions in the country's rich material culture, for instance the T'nalak of women dream weavers of the T'boli tribe in South Cotabato, Philippines. With regards to the environment, some principles of Ecofeminism should be included. Like the experiences of women in confronting some environmental problems and their effort to preserve the environment and pursue environmental-sustainable development.

Grade Four: Ang Bansang Pilipinas. Social Studies Curriculum, or Araling Panlipunan 4, focused in getting to know more about the Philippines and the student's identity as a Filipino. It includes knowledge about basic Philippine geography, Filipino cultural heritage and entrepreneurship, participation in promoting good governance, and dreaming goals for the country. One of the learning competencies in this course states that:

Nasusuri ang papel na ginagampanan ng kultura sa pagbuo ng pagkakakilanlang Pilipino (DepEd, 2013).

Although it is not a direct statement that obviously integrates gender concepts, but it is very clear the need to enlighten the students about gender as social and cultural construction. Filipino identity is not just an interesting topic to be discussed, but it is also 
critical because it should be clear that social norms influence the way one conceptualize or imagine his/her identity. Another competency states that:

Natatalakay ang paraan ng pagpili at ang kaakibat na kapangyarihan ng mga namumuno sa bansa (DepEd, 2013).

With regards to the competency, it should be clear that leadership should not be gender bias. The course should take into consideration feminist leadership and women's contribution in promoting good governance.

Again, in this part of the curriculum rights and duties are being discussed. The teacherfacilitator should capitalize the equality of men and women when it comes to rights and responsibilities as members of a democratic country.

Grade Five: Pagbuo ng Pilipinas Bilang Nasyon. Social Studies Curriculum, or Araling Panlipunan 5, focuses on Philippine History. It highlights the experiences of the Filipino people under the colonial rule and the continuing struggle for nation building and development. The attempt of the course to integrate gender principles are clearly stated in the following learning competencies:

Napaghahambing ang mga tradisyunal at di-tradisyunal na papel ng babe sa lipunan ng sinaunang Pilipino at sa panahon $n g$ kolonyalismo.

Natatalakay ang pangangailangan sa pagpapabuti ng katayuan ng mga babae (DepEd, 2013).

It is obvious from the competencies that the course would highlight women in history and how she was affected by her colonial experiences. It includes transformation of a Filipina across time.

Grade Six: Mga Hamon at Tugon sa Pagkabansa. Social Studies Curriculum, or Araling Panlipunan 6, is the continuation of the discussion of the Philippine history from grade five although the difference is that this course incorporates the use of primary and secondary sources in analyzing the past. There is no particular learning competency that obviously integrates gender concepts and principles.

However, there are certain topics like the Philippine experience from the Spanish period up to the Japanese occupation, where primary sources coming from a female perspective can be employed or used. Other Filipina heroines and politicians or leaders, like Corazon Aquino can also be included in the discourse.

Grade Seven: Araling Asyano. Social Studies Curriculum, or Araling Panlipunan 7, primarily focuses in Asian Studies. It includes discussion about the geography, history, culture, society, politics and the economy of different Asian nation. Courses are also intended to conceptualize Asian identity and to build good relationships among Asian countries. There are some learning competencies in the course that integrates gender-principles:

Nasusuri ang mga kalagayang legal at tradisyin ng mga kababaihan sa iba't ibang uri ng pamumuhay.

\section{Napapahalagahan ang bahaging ginampanan ng kababaihan sa pagtataguyod at pagpapanatili ng mga Asyanong pagpapahalaga (DepEd, 2013).}

In these competencies, the course tries to look on how women are projected in different Asian societies covering the early period up to the present. The course also tries to give value to Asian women's contribution in preserving Asian values. Another competency states that:

Natataya ang epekto ng mga samahang kababaihan at ng mga kalagayang panlipunan sa bahay ng kababaihan tungo sa pagkakapantay-pantay, pagkakataong pang-ekonomiya, at karapatang pampolitika (DepEd, 2013). 
This part highlights the formation of women's movement to call for equality and to uplift the positioning of women in all aspect of the society. It is a very important part because it served as the link of the continuing advocacy for women's participation in government, breaking the glass ceiling, and the call to end discrimination and violence against women.

In addition to the statement above, the course also presents several projects and programs that caters women issues in the contemporary society and advocates the abolishment of several traditions and social norms that violates women's universal rights. These are highly reflected in the following competencies:

\begin{abstract}
Nasusuri at naihahambing ang mga palatuntunang nagtataguyod sa karapatan ng mamamayan sa pangkalahatan, at ng mga kababaihan, mga grupong katutubo, mga kasapi ng caste sa India at iba pang sektor ng lipunan.

Nasusuri ang kalagayan at papel ng kababaihan sa iba't ibang bahagi ng Timog at Kanlurang Asya at ang kanilang ambag sa bansa at rehiyon (DepEd, 2013).
\end{abstract}

\section{Grade Eight: Kasaysayan ng Daigdig.}

Social Studies Curriculum, or Araling Panlipunan 8, is all about World History. It includes discussion about the history, politics, economy, culture, and society of the countries in the world from the ancient time up to the contemporary period.

There is no particular content or competency that obviously incorporates gender principles or at least women issues. But instead, it appears that Araling Panlipunan 8 is a continuation of the Araling Panlipunan 7, but of greater scope. And most of the content are central to the conflicts that involved different countries in the world and agreements and worldwide organizations that were formed after the dispute.

Even though there is no specific content in the curriculum guide that involves women, it is imperative to include in the discourse women's experiences during the conflicts and how these women helped in building good relations among countries in the world thus producing empowered women leaders and advocates.

Grade Nine: Ekonomiks. Social Studies Curriculum, or Araling Panlipunan 9, is all about Economics focusing in the Philippine context. It includes contemporary issues, and some applications of the economic principles to pursue economic development for the country. There is no particular content and learning competencies provided by the curriculum guide that shows integration of gender perspective or at least women's economic issues.

However, to sensitize the course content women's participation in the economy should also be included in the discourse. The role of women in different economic activities covering both the private and public sphere should be clear and well presented to the students to avoid stereotyping and bias.

\section{Grade Ten: Mga Kontemporaryong}

Isyu. Social Studies Curriculum, or Araling Panlipunan 10, is central to different contemporary issues. It covers environmental, socio-cultural, political and economic issues. As well as discussion about human rights, civic rights and responsibilities and the challenges that beset the Philippine society at present.

It appears that among the ten Araling Panlipunan (Social Studies) courses the new curriculum has, the tenth has the most obvious and detailed integration of gender principles and concepts. It can be justified by the following content and their respective learning competencies:

Mga Isyu na may Kaugnayan sa Kasarian or Gender: (1) Gender and Sexuality; (2) Reproductive Health Law; (3) Same-Sex Marriage; and (4) Prostitusyon at Pang-aabuso.

Nakabubuo ng dokyumentaryo na nagsusulong ng paggalang sa karapatan ng mga mamamayan sa pagpiling kasarian at sekswalidad. 
Nasusuri ang iba't ibang salik na nagiging dahilan ng pagkakaroon ng diskriminasyon sa kasarian.

Natatay ang bahaging ginagampanan ng kasarian (gender roles) sa iba't ibang larangan at institusyong panlipunan (trabaho, edukasyon, pamilya, pamahalaan at relihiyon).

Napaghahambing ang katayuan ng kababaihan, lesbians, gays, bisexuals at transgender sa iba't ibang bansa at rehiyon.

Naipapaliwanag ang mahahalagang probisyon ng Reproductive Health Law.

Naipapahayag ang sariling saloobin sa Reproductive Health Law.

Nasusuri ang epekto ng same-sex marriage sa bansa.

Natatalakay ang dahilan ng prostitusyon at pang-aabuso.

Nasusuri ang epekto ng prostitusyon at pangaabuso sa buhay ng tao sa pamayanan at bansa.

Nakapagmumungkahi ng mga paraang tungo sa ikalulutas ang suliranin sa prostitusyon at pang-aabuso sa sariling pamayanan at bansa (DepEd, 2013).

Gender integration covers differentiating gender and sex. It leads to the conceptualization of sexuality. It, then, includes Reproductive health, same-sex marriage, prostitution, and violence. However, it appears from the content that it no longer focus on women's issues alone, but rather it also takes into consideration the LGBTs (Lesbians, Gays, Bisexuals, and Transgender). And it also appears from the competencies that because of the broadness and vastness of the coverage of gender, the curriculum primarily focused on the current issues that conquer the media today as well as issues that are open for debates like the Reproductive Health Law and Same-sex Marriage, for it is what the title of the curriculum suggests.

Even though perspective about gender had already evolved, the course should also look into the role of men and women, and those who have freely chosen their gender on how they can promote gender advocacy and stop the biases, stereotyping, and abuses that the marginalized sectors are experiencing (Kostas, 2009; and Morgen, 2009).

\section{The School as Agent of Social}

Transformation. The Social Studies

Curriculum provided by the Department of Education in the Philippines is the guide that will be followed by most of the schools in the country, both public and private, as it progress in the current educational reform, the K-12 Basic Education Reform. The school is the most influential institution that shapes the mind of the people, and the students in particular. It influences the way the students construct his/her ideas and think of his/her identity as influenced by the society ( $c f$ Rice, 2009; and Schlester, 2009). Therefore, the school and the curriculum should foster culture and gender-responsive environment.

The school and its implementation of the curriculum are critical in responding to the contemporary issues that beset the Philippine society. As DepEd (Department of Education) in the Philippines endeavors to promote transformative education, the Social Studies Curriculum content and learning competencies are designed to recognize gender principles to the teaching-learning process.

The continuing improvement in the curriculum design of Social Studies in the K-12 Basic Education Reform shows that the curriculum is evolving to promote genderfair education. Undeniably, the school serves as a social agent that will turn this endeavor into a reality ( $c f$ Carmody, 2008; and De Guzman ed., 2008).

Promoting gender-fair education is a commitment of different educational institutions in the country, both private and public. For private institutions, St. Scholastica's College and Miriam College offers curricular programs that endeavors to promote an engendered school environment 
(Angeles, 2008; and Gatpandan, 2009). Likewise, the Department of Education in the Philippines produced GAD (Gender and Development) Exemplars that can be used by public schools teachers in integrating gender concepts in their lessons.

The University of the Philippines has a Center for Gender Development and the Philippine Normal University has a University Center for Gender and Development, which both caters on gender issues inside the university, local, and international concerns.

\section{CONCLUSION}

Social Studies is the curriculum vehicle of the K-12 Basic Education Reform to promote active citizenship and social transformation. The new curriculum guide released by the Department of Education in the Philippines described what is the subject all about, its objectives, scope and sequence, and the curriculum content.

The new Social Studies Curriculum of the K-12 Basic Education Reform tries to respond in integrating gender-principles and concepts in the teaching-learning process by providing curriculum content that recognizes women's significance in the society as product historical and cultural processes.

The new Social Studies Curriculum should leads to the conceptualization of sexuality, reproductive health, same-sex marriage, prostitution, and violence as it does not focuses on women's issues alone, but rather it takes into consideration the LGBTs (Lesbians, Gays, Bisexuals, and Transgender) communities at present.

The school serves as an agent of social transformation by creating curriculum that provides learning experiences that will harness social criticism and action towards contemporary issues in the country. The new K-12 Social Studies Curriculum content includes contemporary issues as its way of making the teaching-learning process genderresponsive.
Gender-fair education is an advocacy and commitment. Educational institutions should respond to this endeavor to promote equality and peace in the society. Social Studies is considered as one of the core subjects of the new education reform, because it provide content and learning experiences that will hone the students to become critical, active, engaged, and responsible citizens of the country.

Social Studies Curriculum content should be gender responsive, because it is vital in achieving equality, peace, and development in the country. The school serves as the second agent of socialization; therefore, it should be critical and responsive to the different issues that are being confronted in the society at present.

After conducting this study, the following are hereby recommended: (1) further research about gender-fair education in the Philippine context should be conducted; (2) further research that conducts assessment of the different programs or projects about Gender and Development should be made to give an up-date on the progress of this endeavour; (3) invite resource persons or representatives of agencies, either public or private, to share their best practices in gender-fair education; (4) the study of Philippine institutions and its mechanisms and processes should be strengthened in different teacher-training institutions, so that teachers will be more knowledgeable about the society and the different issues that it confronts; (5) subjects towards establishing gender fair education in schools should be emphasized; (6) reading materials and internet web links that promotes gender fair education should be available in the social institutions; and (7) publications of researches and studies dealing with gender fair education should also be taken into consideration. ${ }^{1}$

${ }^{1}$ Statement: We, hereby, declared that this paper is our original work and not product of plagiarism in any books or journal that have been published. The citation is stated and it is available showed in the References. This paper is never also being submitted and published by other scholarly journal. 


\section{References}

Angeles, Leonora C. (2008). Women's Roles and Status in Philippine History: The Socio-Historical Context of Women's Organizing. Manila: Women's Studies Reader, Institute of Women's Studies, St. Scholastica's College.

Ayo, Ruby Ann L. (2013). “Integrating Gender Fair Education in the Teaching of Philippine History in Bicol University" in TAWARIKH: International Journal for Historical Studies, Vol.4(2), April. Bandung, Indonesia: ASPENSI and UVRI, pp.205-222.

Bowles, Samuel \& Herbert Gintis. (2009). Schooling in Capitalist America: Education and the Contradictions of Economic Life. New York: Basic Books.

Carmody, Gerald V. (2008). The Effects of Gender Based Seating Arrangement on Teacher-Student Interactions. Manila: PNU [Philippine Normal University] Press.

Clark, Margaret \& Carolyn Page. (1999). Understanding the Process of Gender Construction, Gender Equity: A Framework for Australian Schools. New York: Basic Books.

De Guzman, Odine [ed]. (2008). Body Politics: Essays on Cultural Representations of Women's Bodies. Manila: University Center for Women's Studies, University of the Philippines.

DepEd [Department of Education]. (2013). K-12 Gabay Pangkurikulum: Araling Panlipunan, Grades 1 - 10. Manila: Department of Education in the Philippines, December.

Dionisio, Eleanor R. (2008). "More Alike Than Different: Women, Men, and Gender as Social Construction” in Occasional Paper, No.3, NCRFW.

Frankel, A. \& A. Lloyd. (2009). "Changing Schools that Short-Change Girls” in Education Digest, USA [United States of America].

Gatpandan, Eloisa. (2009). Content Analysis of Newspaper Items on Women Published in Philippine Daily Inquirer. Manila: St. Scholastica's College.

Guerrero, Sylvia H. (2008). Women and Gender in Population and Development. Manila: University Center for Women's Studies, University of the Philippines.

Hey, B. (2010). Guidelines on Gender-Fair Curriculum Development. Austria: University of Graz.

Kostas, Nancy Ann. (2009). “A Gender Analysis of Secondary School Physics Textbooks and Laboratory Manuals” in Pro-Quest Absracts, AAC 9814969.

Labajo, M. et al. (2007). Beyond Gender Parity in
Philippine Education: Achieving Gender Equality in and through Education in the Philippines. Manila: PNU [Philippine Normal University] Press.

Landis, Geraldine. (2008). Heroes and Villains: An Analysis of the Treatment of Individuals in World History Textbooks. Manila: PNU [Philippine Normal University] Press.

Lorber, Judith. (2008). The Social Construction of Gender: Paradoxes of Gender. USA [United States of America]: Yale University.

Monk, Janice, Anne Betteridge \& Amy Newhall. (2007). "Reaching for Global Feminism in the Curriculum” in Women's Studies Quarterly.

Morgen, Sandra. (2009). “To See Ourselves, to See Our Sisters: The Challenge of Re-Envisioning Curriculum Change”. A Publication from the Research Clearinghouse and Curriculum Integration Project, Memphis State University Center for Research on Women, USA [United States of America].

NCRFW [National Commission on the Role of Filipino Women]. (2008). Gender and Development Made Easy. Manila: National Commission on the Role of Filipino Women.

NCRFW [National Commission on the Role of Filipino Women]. (2009). Filipino Women: Facts and Figures. Manila: National Commission on the Role of Filipino Women.

NCRFW [National Commission on the Role of Filipino Women]. (2010). Gender and Development Framework. Manila: National Commission on the Role of Filipino Women.

UN [United Nations]. (2013). Beijing Declaration and Platform for Action: Summary. Beijing, China: United Nations Fourth World Conference.

Patajo-Legasto, Priscelina. (2005). "Gender and Curriculum: Is there a Woman in this Class?” in Review of Women's Studies. Manila: University Center for Women's Studies, University of the Philippines.

Perez, Carina E. (2008). A Case Study on Gender Preference in XYZ Company. Manila: St. Scholastica's College.

Reyez, Z. (1998). Selected Asian History Textbooks: A Feminist Critique. Manila: Human Rights Education in Asian Schools.

Reyez, Z. (2012). An Agenda for Gender-Fair Education. Manila: Human Rights Education in Asian Schools.

Rice, Peggy Sue. (2009). Texts and Talk: A Close Look at Gender in Literature Discussion Groups. USA [United States of America]: n.p. [no publisher].

Schlester, Susan L. (2009). A Twelfth Grade Classroom: An English Teacher and Her Students (Feminist Pedagogy). New York, USA [United States of America]: Free Press. 
NERISSA S. TANTENGCO \& RODOLFO L. MARAMAG,

Examining Gender Responsiveness of the Philippine Basic Education Reform

Sobritchea, Carolyn I. [ed]. (2009). Gender Violence: It's Socio-Cultural Dimensions. Manila: University Center for Women's Studies, University of the Philippines.

Tantengco, N. (2001). Assessment of Gender Equity in the Secondary Social Studies Curriculum: Basis for a Proposed Guide in Preparing Gender Fair Instructional Materials. Manila: Centro Escolar University.
UN [United Nations]. (2009). United Nations

Gender Strategy Framework in the Philippines, 2005-2009: Sustaining Women's Human Rights and Gender Equality. Manila: Centro Escolar University.

Wessleyley, L. (2009). Beyond Silenced Voices: Class, Race, and Gender in United States Schools, Albany: State University of the New York Press. 